\section{Factors affecting Brazilians' self-rated health during the COVID-19 pandemic}

\author{
Fatores que afetam a autopercepção de saúde \\ dos brasileiros durante a pandemia da COVID-19
}

\section{Factores que afectan la salud autoevaluada de los brasileños durante la pandemia de COVID-19}

\author{
Celia Landmann Szwarcwald 1 \\ Giseli Nogueira Damacena 1 \\ Marilisa Berti de Azevedo Barros 2 \\ Deborah Carvalho Malta 3 \\ Paulo Roberto Borges de Souza Júnior 1 \\ Luiz Otávio Azevedo 1 \\ Ísis Eloah Machado 4 \\ Margareth Guimarães Lima 2 \\ Dália Romero 1 \\ Crizian Saar Gomes 3 \\ André Oliveira Werneck 5 \\ Danilo Rodrigues Pereira da Silva 6 \\ Renata Gracie 1 \\ Maria de Fátima de Pina 1
}

doi: 10.1590/0102-311X00182720

\begin{abstract}
This is a cross-sectional study investigating the factors affecting brazilians self-rated health during the COVID-19 pandemic, based on data from the web-based behavior survey. Carried out from April 24 to May 24, 2020, the survey recruited participants by a chain sampling procedure. Its outcome was the worsening of self-rated health during the pandemic. Statistical analysis was based on a hierarchical model of determination. Logistic regression models were used to test the associations between sociodemographic characteristics, pre-existing health conditions, lifestyle indicators and intensity of social restraint measures, and biological and psychological issues during the pandemic. From the total sample of 45,161 participants, 29.4\% reported worsening of health state during this period. After adjusting for hierarchical distal factors, the health problems mostly associated with worsening health state were: bad self-rated health (adjusted $O R=4.35, p<0.001$ ), health care seeking for mental health problem (adjusted OR $=3.95, p<0.001$ ), and for COVID-19 (adjusted $O R=3.60, p<0.001$ ). People who experienced sleep problems, worsening of back pain, depression and at least one flu symptom during the pandemic were twice as likely to report worsening of health status. Sedentary and eating behaviors and adherence to social distancing measures showed significant correlation with the outcome. There exists a relation between social, biological, and psychological factors, mediated by lifestyles and variables pertaining to confinement. Altogether, these factors have negatively affected self-rated health during the COVID-19 pandemic in Brazil.
\end{abstract}

\section{Correspondence}

C. L. Szwarcwald

Departamento de Informações para a Saúde, Instituto de Comunicação e Informação Científica e Tecnológica em Saúde, Fundação Oswaldo Cruz.

Av. Brasil 4365, Biblioteca de Manguinhos, sala 225, Rio de Janeiro, RJ 21040-360, Brasil.

celia.szwarcwald@icict.fiocruz.br

\footnotetext{
${ }^{1}$ Instituto de Comunicação e Informação Científica e Tecnológica em Saúde, Fundação Oswaldo Cruz, Rio de Janeiro, Brasil.

2 Faculdade de Ciências Médicas, Universidade Estadual de Campinas, Campinas, Brasil.

3 Escola de Enfermagem, Universidade Federal de Minas Gerais, Belo Horizonte, Brasil.

${ }_{4}$ Escola de Medicina, Universidade Federal de Ouro Preto, Ouro Preto, Brasil.

5 Faculdade de Saúde Pública, Universidade de São Paulo, São Paulo, Brasil.

${ }_{6}^{6}$ Departamento de Educação Física, Universidade Federal de Sergipe, Aracaju, Brasil.
} 


\section{Introduction}

In December 2019, cases of severe infectious respiratory disease were reported in Wuhan, Hubei Province, China. The novel coronavirus (SARS-CoV-2) has been found to be the agent of this disease, named coronavirus disease 2019 (COVID-19) by the World Health Organization (WHO) 1. Since the first reported case, the outbreak has rapidly spread across China and worldwide in a short period, with an explosive increase in several countries, reaching around 6 million diagnosed cases and more than 350,000 deaths worldwide from December, 2019 to the end of May, 20202.

On March 11, 2020, the WHO classified the novel coronavirus epidemic as a pandemic 3. In Brazil, the first COVID-19 case was identified on February 26. By the end of May, the government reported more than 500,000 cases, with roughly 30,000 deaths and 5.7\% lethality rate (https://bigdata-covid 19 . icict.fiocruz.br/).

The COVID-19 pandemic is forcing the implementation of drastic measures worldwide to control the massive spread. Besides timely diagnosis and case isolation, public health measures to contain the disease spread include quarantine and social distancing measures 4.

Although most people have not yet experienced quarantine, this public health measure had been established in the past 5 to control the SARS and MERS epidemics. Some areas in China and Canada imposed community quarantines during the 2003 outbreak of severe acute respiratory syndrome (SARS), while entire villages in many West African countries were quarantined during the 2014 Ebola public health emergency 6 .

During the COVID-19 pandemic, to avoid the overload of health systems ${ }^{7}$ and to delay the spread of infected cases, several countries are implementing measures of social restraint, ranging from the closure of schools and commercial establishments to national quarantines 4 . The first measures were adopted by China, where entire cities became effectively quarantined 8 . Currently, a large part of the world population is under some form of restriction to avoid crowding 4.

The arrival of the COVID-19 pandemic in Brazil has led to a series of initiatives and recommendations for protecting the population. Since March, public health measures like confinement and social distancing have been adopted in the main Brazilian cities as well as lockdown of small cities to prevent the entry of cases from the metropoles. Schools and non-essential businesses have been closed, workers have been instructed to carry out activities from home, some cities and states have closed borders, and travels have been restricted 9 .

Motivated by the preliminary results of the ConVid - Behavior Survey, a web-based population survey conducted in Brazil (http://www.convid.icict.fiocruz.br), which indicated the worsening of several health problems and the practice of unhealthy behaviors during the COVID-19 pandemic, the present study aims at establishing the most important factors affecting Brazilians' self-rated health.

\section{Methods}

This cross-sectional study used data from the web-based ConVid - Behavior Survey carried out in Brazil from April 24 to May 24, 2020. An online questionnaire was used to assess changes in lifestyles, routine activities, psychological issues, health conditions, and access to health care during the COVID-19 pandemic in the country. The survey was elaborated by the Oswaldo Cruz Foundation (Fiocruz), in partnership with the Federal University of Minas Gerais (UFMG) and the State University of Campinas (UNICAMP) and a group of researchers from other Brazilian academic institutions. The project was approved by the Brazilian National Research Ethics Commission (Process number 3.980.277).

For data collection and management, the researchers used the RedCap (Research Electronic Data Capture; https://www.redcapbrasil.com.br) application. Self-completed using a cell phone or laptop/ computer with internet access, all responses to the questionnaire were completely anonymous. The information was directly stored on the server of the Institute of Communication and Scientific and Technological Information in Health (ICICT/Fiocruz). Inclusion criteria were being 18 years old or over and being a Brazilian citizen residing in the country during the pandemic. Further details are available at the ConVid - Behavior Survey website (http://www.convid.icict.fiocruz.br). 
Participants were invited through a chain sampling procedure. In the first stage, a total of 200 other researchers from different Brazilian states were chosen to start the sampling chain. In addition, each researcher selected 20 people from their social network, totaling roughly 500 people initially chosen to comprise the seeds of the chain. Each seed sent the survey link to at least 12 people from their social networks, obeying a stratification by gender, age group (18-39; 40-59; 60+ years) and educational level (incomplete high school or less; complete high school; complete college education or over), so at least 3 people in each strata participated in the survey. The participants invited by the seeds made up the second wave of the recruitment chain. Each person in the second wave was asked to invite at least three other people from their social networks, and so on. At the end of the data collection (April 24 to May 24, 2020), the sample reached 45,161 people.

The sample was weighted using data from the 2019 Brazilian National Household Sample Survey (PNAD 2019) from the Brazilian Institute of Geography and Statistics (IBGE) to obtain the same sample distribution by state, gender, age group, skin color, and educational level of the Brazilian population. Further details of the survey methodology can be found in Szwarcwald et al. 10.

For the statistical analysis, self-rated health was used to assess the overall health status: "Overall, how do you rate your health?" (very good; good; regular; bad). Changes in health status during the pandemic was assessed by the following question: "Do you think the pandemic caused changes in your health?" (got better; stayed the same; got a little worse; got a lot worse). In this study, the outcome was the worsening of self-rated health (got a little or a lot worse) during the COVID-19 pandemic.

To analyze the factors associated with the outcome, we used a hierarchical model of determination 11,12. This type of analysis considers the association of each variable with the outcome, controlling for possible confounder effects between proximal and distal variables. We developed our conceptual model to integrate social, behavioral, psychological, and biological factors to explain their relations with worsening of health status during the pandemic. The model includes factors that have traditionally been identified as relevant to self-evaluation of health including sociodemographic variables 13 , behavioral factors 14 , non-communicable chronic diseases 15 , as well as clinical and psychological issues occurring during the pandemic.

The independent variables were organized into four hierarchical blocks (one distal, two intermediary, and one proximal) and used throughout the statistical analysis: sociodemographic characteristics; pre-existing health conditions; lifestyle indicators and adherence to social restriction measures during the pandemic; and health problems occurring during the pandemic. The proximal variables (block 4) were health care seeking, flu symptoms, and clinical and psychological problems during the pandemic, which may affect the outcome directly. Hierarchically above and considered in parallel, the intermediary variables were subdivided into group 2 - pre-existing health conditions, which may influence clinical and psychological issues during the pandemic, and group 3 - behavioral variables (including adherence to social restriction measures) during the pandemic, which may affect the health status through intermediate mechanisms 16 . Lastly, socioeconomic variables and individual characteristics such as age and gender acted as distal determinants, which may interfere in noncommunicable diseases and lifestyles 17 during the pandemic.

Block 1 comprised the sociodemographic characteristics: gender, age groups (18-29; 30-44; 45-59; 60+ years), skin color (white; non-white), and income per capita based on the monthly minimum wage in Brazil - around USD $200.00(<1 / 2 ; 1 / 2-1 ; 1-2 ; \geq 2)$.

Block 2 addressed pre-existing health conditions: general self-rated health; previous diagnosis of chronic non-communicable diseases (hypertension, diabetes, asthma/emphysema/chronic respiratory disease/other lung disease, heart disease, depression); usual sleep problems; and chronic back pain.

Among the behavioral indicators during the pandemic (block 3), the analysis included: increase in usual alcohol consumption; increase in the daily number of cigarettes among smokers; consumption of sweets/chocolates on 2 or more days a week; consumption of vegetable and fruit on 5 days or more a week; recommended physical activity (150 minutes or more a week); and sedentary behaviors measured by hours/day watching television and using a computer/tablet. Additionally, adherence to social restraint measures during the pandemic (no or little restriction; intense social restriction people leaving only for grocery stores and pharmacies; total social restriction - people leaving only for health care needs) was also included in this block. 
As to health conditions occurring during the pandemic (block 4), we considered: psychological issues (frequent feelings of depression, anxiety, and loneliness); worsening of sleep quality (got worse or started to have sleep problems); health care seeking (COVID-19 symptoms, mental health problems, or other health problems during the pandemic); at least one flu symptom during the COVID-19 pandemic; and back pain status during the pandemic (got worse or started to have pain).

Initially, we analyzed the blocks separately performing, for each block of variables, a descriptive analysis of each variable, and estimating the prevalence of worsening health status for each variable category. To assess the possible factors associated with the outcome, we used logistic regression models to test at the $1 \%$ significance level the associations of health state worsening during the pandemic period with the variables of each hierarchical block. The estimated odds ratio (OR) and the respective $95 \%$ confidence interval (95\%CI) was used as the measure of association.

For the multivariate analysis, the variable bocks were inserted sequentially and hierarchically, starting with the sociodemographic block, followed by the pre-existing health conditions and behavior indicators, and lastly the variables related to the pandemic. Variables with p-values $<0.01$ in each block analysis were included in the multivariate model. Only variables with a $\mathrm{p}$-value $<0.01$ remained in the final multivariate analysis.

\section{Results}

From the total of 45,161 adults analyzed, $46.4 \%$ were male and $53.6 \%$ female (Table 1 ). In the total sample, $29.4 \%$ reported worsening of health state.

Table 1 describes the associations between the outcome and sociodemographic characteristics. The results showed differences by gender, with women experiencing a significantly higher proportion of health state worsening than men. Regarding age groups, worsening of self-rated health was

\section{Table 1}

Sociodemographic characteristics and associations with health worsening perception during the COVID-19 pandemic. Brazil, 2020.

\begin{tabular}{|c|c|c|c|c|c|}
\hline Variable/Category & $\mathbf{n}$ & $\%$ & $\begin{array}{c}\text { Health state } \\
\text { worsening (\%) }\end{array}$ & OR & $95 \% \mathrm{Cl}$ \\
\hline Total sample & 45,161 & - & 29.4 & - & - \\
\hline \multicolumn{6}{|l|}{ Gender } \\
\hline Male & 20,975 & 46.4 & 24.9 & 1.00 & - \\
\hline Female & 24,186 & 53.6 & 33.4 & 1.51 & $1.45-1.58$ \\
\hline \multicolumn{6}{|l|}{ Age group (years) } \\
\hline $18-29$ & 11,142 & 24.7 & 39.3 & 2.69 & $2.52-2.87$ \\
\hline $30-39$ & 9,492 & 21.0 & 33.6 & 2.10 & $1.96-2.24$ \\
\hline $40-49$ & 8,164 & 18.1 & 27.3 & 1.56 & $1.45-1.67$ \\
\hline $50-59$ & 7,190 & 15.9 & 23.8 & 1.30 & $1.20-1.40$ \\
\hline $60+$ & 9,173 & 20.3 & 19.4 & 1.00 & - \\
\hline \multicolumn{6}{|l|}{ Skin color } \\
\hline White & 20,423 & 45.2 & 26.9 & 0.80 & $0.77-0.83$ \\
\hline Non white & 24,738 & 54.8 & 31.5 & 1.00 & - \\
\hline \multicolumn{6}{|l|}{ Per capita income * } \\
\hline$<1 / 2$ & 11,893 & 28.1 & 33.5 & 1.45 & $1.37-1.53$ \\
\hline $1 / 2-1$ & 9,103 & 21.5 & 29.4 & 1.20 & $1.12-1.27$ \\
\hline $1-2$ & 10,409 & 24.6 & 27.9 & 1.11 & $1.05-1.18$ \\
\hline$\geq 2$ & 10,980 & 25.9 & 25.8 & 1.00 & - \\
\hline
\end{tabular}

95\% Cl: 95\% confidence interval; OR: odds ratio.

* Monthly minimum wage in Brazil around USD 200.00. 
inversely and significantly correlated with age: the lower the age, the higher the percentage, varying from $19.4 \%$, among older adults, to $39.3 \%$, among young adults (18-29 years). Per capita income was also a significant correlate: among the less affluent, chances of reporting health worsening was 1.45 higher than among the most affluent. Although skin color showed less correlation, white people reported a less affected health status.

In Table 2, we analyze the pre-existing health problems. Regarding self-rated health, 26\% evaluated their health as regular/poor. For those with not good self-rated health, the proportion of health state worsening was significantly higher $(\mathrm{OR}=4.75, \mathrm{p}<0.001)$. Among people with previous diagnosis of a chronic non-communicable disease, depression showed the highest association with the outcome $(\mathrm{OR}=2.40, \mathrm{p}<0.001)$, followed by asthma/emphysema/chronic respiratory disease/other lung disease $(\mathrm{OR}=1.42, \mathrm{p}<0.001)$, and heart disease diagnosis $(\mathrm{OR}=1.37, \mathrm{p}<0.001)$. Usual sleep problems $(\mathrm{OR}=1.85, \mathrm{p}<0.001)$ and chronic back pain $(\mathrm{OR}=1.41, \mathrm{p}<0.001)$ were also significantly associated with the outcome.

Table 3 comprises the associations between the outcome and behavioral indicators. The results show that $34 \%$ of usual smokers increased their daily number of cigarettes, with increased number of cigarettes significantly affecting self-perception of health state worsening $(\mathrm{OR}=2.00, \mathrm{p}<0.001)$, as well as the increase in alcohol consumption $(\mathrm{OR}=1.32, \mathrm{p}<0.001)$. Physical activity for 150 minutes or over a week was inversely correlated with the outcome $(\mathrm{OR}=0.62, \mathrm{p}<0.001)$ but only $12 \%$ of the sample practiced sufficient physical activity during the pandemic. On the other hand, the two indica-

Table 2

Pre-existing health problems and associations with health worsening perception during the COVID-19 pandemic. Brazil, 2020

\begin{tabular}{|c|c|c|c|c|c|c|}
\hline Variable/Category & $\mathbf{n}$ & $\%$ & Health state worsening (\%) & OR & $95 \% \mathrm{Cl}$ & p-value \\
\hline \multicolumn{7}{|l|}{ Self-rated health } \\
\hline Not good & 11,733 & 26.0 & 55.0 & 4.75 & $4.54-4.97$ & $<0.001$ \\
\hline Good & 33,379 & 74.0 & 20.4 & 1.00 & - & - \\
\hline \multicolumn{7}{|c|}{ Diagnosis of hypertension } \\
\hline Yes & 8,705 & 19.3 & 28.1 & 0.93 & $0.88-0.98$ & 0.004 \\
\hline No & 36,456 & 80.7 & 29.7 & 1.00 & - & - \\
\hline \multicolumn{7}{|l|}{ Diagnosis of diabetes } \\
\hline Yes & 3,262 & 7.2 & 31.6 & 1.12 & $1.04-1.21$ & 0.005 \\
\hline No & 41,899 & 92.8 & 29.2 & 1.00 & - & - \\
\hline \multicolumn{7}{|c|}{ Diagnosis of lung disease * } \\
\hline Yes & 5,104 & 11.3 & 36.2 & 1.42 & $1.34-1.51$ & $<0.001$ \\
\hline No & 40,057 & 88.7 & 28.6 & 1.00 & - & - \\
\hline \multicolumn{7}{|c|}{ Diagnosis of heart disease } \\
\hline Yes & 1,961 & 4.3 & 36.0 & 1.37 & $1.25-1.51$ & $<0.001$ \\
\hline No & 43,200 & 95.7 & 29.1 & 1.00 & - & - \\
\hline \multicolumn{7}{|c|}{ Diagnosis of depression } \\
\hline Yes & 6,710 & 14.9 & 46.3 & 2.40 & $2.27-2.53$ & $<0.001$ \\
\hline No & 38,451 & 85.1 & 26.5 & 1.00 & - & - \\
\hline \multicolumn{7}{|l|}{ Chronic back pain } \\
\hline Yes & 15,194 & 33.8 & 34.2 & 1.41 & $1.35-1.47$ & $<0.001$ \\
\hline No & 29,642 & 66.2 & 27.0 & 1.00 & - & - \\
\hline \multicolumn{7}{|l|}{ Usual sleep problems } \\
\hline Yes & 29,735 & 66.1 & 25.0 & 1.85 & $1.77-1.92$ & $<0.001$ \\
\hline No & 15,250 & 33.9 & 33.9 & 1.00 & - & - \\
\hline
\end{tabular}

95\%Cl: 95\% confidence interval; OR: odds ratio.

* Asthma/emphysema/chronic respiratory disease/other lung disease. 
Table 3

Behavioral indicators and associations with health worsening perception during the COVID-19 pandemic. Brazil, 2020.

\begin{tabular}{|c|c|c|c|c|c|c|}
\hline Variable/Category & $\mathbf{n}$ & $\%$ & $\begin{array}{c}\text { Health state } \\
\text { worsening (\%) }\end{array}$ & OR & $95 \% \mathrm{Cl}$ & p-value \\
\hline \multicolumn{7}{|c|}{ Increase in the number of cigarettes } \\
\hline Yes & 1,807 & 34.0 & 38.8 & 2.00 & $1.77-2.23$ & $<0.001$ \\
\hline No & 3,500 & 66.0 & 24.0 & 1.00 & - & - \\
\hline \multicolumn{7}{|c|}{ Increase in alcohol use } \\
\hline Yes & 3,726 & 8.3 & 34.8 & 1.32 & $1.22-1.43$ & $<0.001$ \\
\hline No & 41,001 & 91.7 & 28.8 & 1.00 & - & - \\
\hline \multicolumn{7}{|c|}{ Physical activity $\geq 150$ minutes a week } \\
\hline No & 39,051 & 88.0 & 30.5 & 1.00 & - & - \\
\hline Yes & 5,329 & 12.0 & 21.5 & 0.62 & $0.58-0.67$ & $<0.001$ \\
\hline \multicolumn{7}{|l|}{ TV-watching increase } \\
\hline Yes & 27,628 & 61.8 & 33.3 & 1.68 & $1.61-1.75$ & $<0.001$ \\
\hline No & 17,111 & 38.2 & 23.0 & 1.00 & - & - \\
\hline \multicolumn{7}{|c|}{ Tablet/Laptop using increase } \\
\hline Yes & 23,058 & 53.6 & 33.4 & 1.56 & $1.50-1.63$ & $<0.001$ \\
\hline No & 19,928 & 46.4 & 24.3 & 1.00 & - & - \\
\hline \multicolumn{7}{|c|}{ Vegetable and fruit consumption $\geq 5$ days a week } \\
\hline Yes & 9,743 & 21.8 & 23.2 & 0.67 & $0.64-0.71$ & $<0.001$ \\
\hline No & 34,986 & 78.2 & 31.1 & 1.00 & - & - \\
\hline \multicolumn{7}{|c|}{ Chocolate and sweet consumption $\geq 2$ days a week } \\
\hline Yes & 20,536 & 47.1 & 33.3 & 1.41 & $1.35-1.46$ & $<0.001$ \\
\hline No & 23,065 & 52.9 & 26.2 & 1.00 & - & - \\
\hline \multicolumn{7}{|c|}{ Intensity of social restriction } \\
\hline No & 11,572 & 25.8 & 25.9 & 1.00 & - & - \\
\hline Intense & 26,572 & 59.2 & 30.3 & 1.25 & $1.19-1.31$ & $<0.001$ \\
\hline Total & 6,770 & 15.1 & 32.9 & 1.40 & $1.31-1.50$ & $<0.001$ \\
\hline
\end{tabular}

95\%Cl: 95\% confidence interval; OR: odds ratio.

tors of sedentary behaviors during the pandemic, TV-watching and tablet/laptop use were frequent behaviors during the pandemic and were significantly associated with worsening of health state $(\mathrm{OR}=1.68, \mathrm{p}<0.001 ; \mathrm{OR}=1.56, \mathrm{p}<0.001)$. Only $21.8 \%$ consumed fruits and vegetables for 5 days or more a week during the pandemic, showing inversely correlation with health state worsening $(\mathrm{OR}=0.67, \mathrm{p}<0.001)$. Almost $50 \%$ consumed chocolates and sweets for 2 days or more a week, what significantly influenced the perception of health state worsening $(\mathrm{OR}=1.41, \mathrm{p}<0.001)$. As to social restriction measures, 59.2\% showed intense adherence and 15.1\% total adherence, that is, leaving home only for medical needs. Total and intense adherence were associated with worsening of health status during the pandemic: $\mathrm{OR}=1.40(\mathrm{p}<0.001)$ and $\mathrm{OR}=1.25(\mathrm{p}<0.001)$, respectively.

In Table 4, we present the associations of clinical and psychological issues during the pandemic with worsening of self-rated health. Seeking health care for a mental health problem was the most associated factor with the outcome $(\mathrm{OR}=5.74, \mathrm{p}<0.001)$, followed by COVID-19 symptoms $(\mathrm{OR}=$ $4.71, \mathrm{p}<0.001)$. Having flu symptoms during the pandemic was associated with the outcome, as well $(\mathrm{OR}=2.53, \mathrm{p}<0.001)$. Among the self-reported psychological issues, anxiety $(52.6 \%)$ and depression (40.4\%) showed strong association with health state evaluation, with participants being four times more likely to report health state worsening when compared to people without those issues. The chances of health state worsening was two times greater among those reporting loneliness $(\mathrm{OR}=$ $2.17, \mathrm{p}<0.001)$. Worsening of sleep problems also showed important association with the outcome: $16.3 \%$ reported worsening of sleep problems and were five times more likely to report health state 
Table 4

Health problems during the COVID-19 pandemic and associations with health worsening perception. Brazil, 2020.

\begin{tabular}{|c|c|c|c|c|c|c|}
\hline Variable/Category & $\mathbf{n}$ & $\%$ & $\begin{array}{c}\text { Health state } \\
\text { worsening (\%) }\end{array}$ & OR & $95 \% \mathrm{Cl}$ & p-value \\
\hline \multicolumn{7}{|l|}{ Health care seeking } \\
\hline No & 35,234 & 78.3 & 26.1 & 1.00 & - & - \\
\hline COVID-19 symptoms & 1,600 & 3.6 & 62.5 & 4.71 & $4.24-5.22$ & $<0.001$ \\
\hline Mental health problems & 329 & 0.7 & 67.0 & 5.74 & $4.56-7.24$ & $<0.001$ \\
\hline Other health problems & 7,817 & 17.4 & 35.4 & 1.55 & $1.47-1.63$ & $<0.001$ \\
\hline \multicolumn{7}{|l|}{ At least one flu symptom } \\
\hline Yes & 12,670 & 28.1 & 44.0 & 2.53 & $2.42-2.64$ & $<0.001$ \\
\hline No & 32,396 & 71.9 & 23.7 & 1.00 & - & - \\
\hline \multicolumn{7}{|l|}{ Depression } \\
\hline Yes & 18,173 & 40.4 & 46.5 & 4.00 & $3.83-4.17$ & $<0.001$ \\
\hline No & 26,828 & 59.6 & 17.8 & 1.00 & - & - \\
\hline \multicolumn{7}{|l|}{ Anxiety } \\
\hline Yes & 23,721 & 52.6 & 42.4 & 4.21 & $4.02-4.41$ & $<0.001$ \\
\hline No & 21,352 & 47.4 & 14.9 & 1.00 & - & - \\
\hline \multicolumn{7}{|l|}{ Loneliness } \\
\hline Yes & 25,665 & 56.9 & 36.0 & 2.17 & $2.07-2.26$ & $<0.001$ \\
\hline No & 19,412 & 43.1 & 20.6 & 1.00 & - & - \\
\hline \multicolumn{7}{|l|}{ Worsening of sleep problems } \\
\hline No & 24,715 & 54.9 & 17.1 & 1.00 & - & - \\
\hline Got worse & 7,324 & 16.3 & 52.8 & 5.42 & $5.12-5.73$ & $<0.001$ \\
\hline Started to have & 12,946 & 28.8 & 39.9 & 3.22 & $3.07-3.38$ & $<0.001$ \\
\hline \multicolumn{7}{|l|}{ Worsening of back pain } \\
\hline No & 24,440 & 54.5 & 19.4 & 1.00 & - & - \\
\hline Got worse & 8,263 & 18.4 & 45.1 & 3.41 & $3.24-3.60$ & $<0.001$ \\
\hline Started to have & 12,133 & 27.1 & 38.8 & 2.63 & $2.51-2.76$ & $<0.001$ \\
\hline
\end{tabular}

95\%Cl: 95\% confidence interval; OR: odds ratio.

worsening when compared with people without changes in sleep quality; $28.8 \%$ started to experience sleep problems during the pandemic and were three times more likely to report worsening of health. Regarding back pain, 27.1\% started to experience back pain during the pandemic and 18.4\% reported worsening of back pain. Both back pain indicators showed highly significant associations with the outcome $(\mathrm{OR}=2.63, \mathrm{p}<0.001 ; \mathrm{OR}=3.41, \mathrm{p}<0.001)$, respectively.

In Table 5, we present the results of the hierarchical logistic regression model. After controlling for sex, age group, skin color and per capita income we analyzed the associations of block 2 and block 3 variables. Associations with the proximal variables (block 4) were analyzed after controlling for all other variables. The following health problems were strongly associated with worsening health status: health care seeking for mental health problem (adjusted $\mathrm{OR}=3.95, \mathrm{p}<0.001$ ) and health care seeking for COVID-19 symptoms during the pandemic (adjusted OR $=3.60, \mathrm{p}<0.001$ ). People who experienced sleep problems, worsening of back pain, depression and at least one flu symptom during the pandemic were twice as likely to report health state worsening. Anxiety and loneliness and health care seeking for other reasons remained significantly associated with the outcome although with weaker OR (smaller than 1.4). Among pre-existing health conditions, bad self-rated health was the most 
Table 5

Most associated indicators with health worsening perception during the COVID-19 pandemic. Brazil, 2020.

\begin{tabular}{|c|c|c|c|}
\hline Variable/Category & Adjusted OR & $95 \% \mathrm{Cl}$ & p-value \\
\hline \multicolumn{4}{|l|}{ Previous health conditions * } \\
\hline Bad self-rated health & 4.35 & 4.14-4.58 & $<0.001$ \\
\hline Diagnosis of depression & 1.62 & $1.52-1.72$ & $<0.001$ \\
\hline Sleep problems & 1.32 & $1.25-1.38$ & $<0.001$ \\
\hline Usual back pain & 1.31 & $1.24-1.38$ & $<0.001$ \\
\hline Diagnosis of heart disease & 1.19 & $1.06-1.33$ & 0.003 \\
\hline \multicolumn{4}{|l|}{ Behavioral indicators * } \\
\hline Physical activity $\geq 150$ minutes a week & 0.69 & $0.63-0.74$ & $<0.001$ \\
\hline TV-watching increase & 1.36 & $1.30-1.43$ & $<0.001$ \\
\hline Tablet/Laptop use increase & 1.38 & $1.32-1.45$ & $<0.001$ \\
\hline Vegetables and fruits consumption $\geq 5$ days a week & 0.73 & $0.69-0.78$ & $<0.001$ \\
\hline Chocolates and sweets consumption $\geq 2$ days a week & 1.24 & $1.18-1.30$ & $<0.001$ \\
\hline Increase in alcohol use & 1.25 & $1.15-1.35$ & $<0.001$ \\
\hline Total social restriction & 1.49 & $1.38-1.61$ & $<0.001$ \\
\hline Intense social restriction & 1.10 & 1.04-1.17 & $<0.001$ \\
\hline \multicolumn{4}{|l|}{ Health conditions during the pandemic ** } \\
\hline Health care seeking for COVID-19 symptoms & 3.60 & $3.14-4.12$ & $<0.001$ \\
\hline Health care seeking for mental health problems & 3.95 & $2.81-5.54$ & $<0.001$ \\
\hline Health care seeking for other health problems & 1.14 & $1.07-1.22$ & $<0.001$ \\
\hline At least one flu symptom & 1.77 & $1.68-1.87$ & $<0.001$ \\
\hline Worsening of sleep problems & 2.15 & $2.00-2.31$ & $<0.001$ \\
\hline Started to have sleep problems & 2.10 & $1.93-2.30$ & $<0.001$ \\
\hline Worsening of back pain & 2.12 & $1.94-2.32$ & $<0.001$ \\
\hline Started to have back pain & 1.58 & $1.48-1.69$ & $<0.001$ \\
\hline Depression & 1.81 & $1.70-1.93$ & $<0.001$ \\
\hline Anxiety & 1.38 & $1.29-1.48$ & $<0.001$ \\
\hline Loneliness & 1.16 & $1.09-1.23$ & $<0.001$ \\
\hline
\end{tabular}

95\% Cl: 95\% confidence interval; OR: odds ratio.

* Adjusted OR after controlling for sociodemographic characteristics (gender, age group, skin color, and per capita income);

** Adjusted OR after controlling for sociodemographic characteristics (gender, age group, skin color, and per capita income), previous health conditions, and lifestyles indicators.

associated factor with the outcome (adjusted $\mathrm{OR}=4.35, \mathrm{p}<0.001$ ). Previous diagnosis of depression and heart disease, usual sleep problems and previous back pain significantly affected the outcome, as well. As to behavioral variables, total and intense adherence to social restriction measures, sedentary behaviors, increase in alcohol use, and chocolates and sweets consumption for two days or over a week negatively affected health status perception during the pandemic. The only factors significantly and inversely correlated with the outcome were practice of sufficient physical activity and vegetable and fruit intake on five days or more a week during the pandemic. 


\section{Discussion}

This study used a hierarchical model to identify the most important predictors of worsening of health status during the COVID-19 pandemic. The main proximal factors were seeking care for mental health problems and COVID-19 symptoms, as well as self-reported psychological issues. As to intermediate behavioral indicators, healthy food intake and physical activity practice during the pandemic showed a positive influence on health state perception while sedentary habits and adherence to social restraint measures negatively affected health status evaluation. Considering pre-existing health conditions, worsening of health status was greater among those with poor self-rated health. In turn, association with the distal variables corroborate previous results with less affluent people being more affected than the most affluent 18 .

Largely used as a morbidity indicator in health surveys, self-rated health is useful for its validity, established by their relations with the individual's clinical conditions and with morbidity and mortality indicators 19,20. In the context of the COVID-19 pandemic in Brazil, health care seeking for COVID-19 symptoms was one of the greater predictors of health worsening perception. This finding corroborates previous studies, suggesting that individual feelings create a poor health state perception even before medical diagnosis of the disease 21 .

While medical evaluation refers to disease diagnosis indicated by a set of signals, symptoms, and laboratory results, self-rated health is subjective, combining physical, emotional, and well-being components 22,23 . Our findings reinforce the influence of emotional conditions on health state evaluation 24,25. Psychological issues such as depression and anxiety as well as worsening of sleep problems, reported by a large proportion of participants, were central for understanding the perception of health worsening. Particularly among young adults (18-29 years old), these psychological issues were often reported and negatively affected their health status. Perceived social isolation, commonly termed loneliness, was also associated with the outcome 26 .

Although the health value of quarantine remains essential, coping with social restraint measures are challenging factors. Reviewing past outbreak articles, most studies reported negative psychological effects 27 . A study in Turkey during the current pandemic showed that uncertainty and fears related to COVID-19 have direct and significant effects on mental wellbeing ${ }^{28}$. Lack of information, fake news, and misinformation are likely to reinforce the panic leading to anxiety and other mental health issues 27.

Another factor negatively affecting health status is the postponement of medical assistance for problems not related to COVID-19. Due to the exhausted capacity of health services or for fear of becoming infected in health care units, medical appointments have been canceled or people have postponed routine health care. In Brazil, 36\% of adults with previous diagnosis of heart disease reported worsening of health status. France showed a dramatic drop in the number of cardiovascular admissions after establishing social confinement measures 29 .

In Brazil, quarantine has been firstly adopted in São Paulo in March 2020 and was followed by strict social distancing measures in all other states in the country, travel restrictions, and lockdowns in some cities 9 . Separation from loved ones, loss of freedom, uncertainty about the disease, and changes in routine activities have led to distress, anxiety and depression, generating relevant psychological problems and adoption of unhealthy behaviors. Our results show an increase in the daily number of cigarettes among smokers, in alcohol consumption, in chocolate and sweets consumption, a reduction in physical activity, and increase in TV-watching and tablet/laptop use. All these unhealthy habits show negative associations with self-rated health status, corroborating results of previous studies 30,31,32.

As the adoption of healthy behaviors has been growing in Brazil, notably the decrease in the use of tobacco products 33 , the increase in the daily number of cigarettes represents a step backwards, meaning that health policies aimed at reducing the use of tobacco products will need to be strengthened. On the other hand, fruits and vegetables intake for five days or more a week as well as regular physical activity during the pandemic showed a positive influence on health state perception. As previously discussed, Brazilians are already associating healthy behaviors to their well-being 34 .

Efforts are also being made to encourage the practice of physical activities 35 . Domestic confinement, however, caused a substantial decrease in regular exercise. Prolonged bouts of sedentary behaviors result in various health risks, including increased levels of stress, depression, and anxiety 36 , 
as opposed to regular physical activity, which releases endorphins and provide a feeling of well-being and tension relief 37 . In addition, sedentary behaviors and changes in routine and work activities during confinement aggravate chronic back pain 38 , one of the greater predictors of worsening health status.

One limitation of the web-based ConVid - Behavior Survey is the involuntary exclusion of lowincome people who do not have internet access, either by cell phone or computer, and thus unable to participate in the survey. Although the sample weighting with national household data contributed to obtain a similar sample distribution to that of the national population, this segment remained under-represented. As for the sample geographic distribution, all states featured in the survey. After data weighting, the sample was representative of macro-regions, but over-representative of the state capitals. The dependence of observations resulting from the chain recruitment sampling may also have caused bias on the estimates ${ }^{39}$. We cannot also disregard the possibility of bias inherent to crosssectional studies due to the lack of follow up of health events 40 . Finally, as in other national health surveys, large sample sizes are likely to find significant relationships even when the strength of the association is weak. In this study, associations were tested at the $1 \%$ level of significance to minimize this problem.

On the other hand, sample limitations of under or over representation have been reduced due to the sample size. Comparison with the 2013 Brazilian National Health Survey data shows our sample is representative of diabetes prevalence, smoking status, chronic back pain, among many other health indicators 41 .

In conclusion, there exists a relation between social, biological, and psychological factors, mediated by lifestyles and variables pertaining to confinement and isolation from immediate social circle, such as family, neighbors, and community. Altogether, these factors have negatively affected Brazilians' self-rated health during the COVID-19 pandemic.

\section{Contributors}

C. L. Szwarcwald participated in the conception, planning, data analysis and interpretation and text writing. G. N. Damacena, M. B. A. Barros and D. C. Malta contributed in the data analysis and interpretation and text writing. P. R. B. Souza Júnior, L. O. Azevedo, I. E. Machado, M. C. Lima, D. Romero, C. S. Gomes, A. O. Werneck, D. R. P. Silva, R. Gracie and M. F. Pina contributed in the data discussion and text writing

\section{Additional informations}

ORCID: Celia Landmann Szwarcwald (0000-00027798-2095); Giseli Nogueira Damacena (00000002-7059-3353); Marilisa Berti de Azevedo Barros (0000-0003-3974-195X); Deborah Carvalho Malta (0000-0002-8214-5734); Paulo Roberto Borges de Souza Júnior (0000-0002-8142-4790); Luiz Otávio Azevedo (0000-0002-4876-5948); Ísis Eloah Machado (0000-0002-4678-2074); Margareth Guimarães Lima (0000-0001-6996-0745); Dália Romero (0000-0002-2643-9797); Crizian Saar Gomes (0000-0001-6586-4561); André Oliveira Werneck (0000-0002-9166-4376); Danilo Rodrigues Pereira da Silva (0000-0003-3995-4795); Renata Gracie (0000-0003-0225-3696); Maria de Fátima de Pina (0000-0002-1521-7865). 


\section{References}

1. Chakraborty I, Maity P. COVID-19 outbreak: Migration, effects on society, global environment and prevention. Sci Total Environ 2020; 728:138882.

2. World Health Organization. Coronavirus disease (covid-19) situation report - 132. https:// www.who.int/emergencies/diseases/novelcoronavirus-2019/situation-reports (accessed on 31/May/2020)

3. World Health Organization. WHO DirectorGeneral's opening remarks at the media briefing on COVID 19. https://www.who.int/dg/ speeches/detail/who-director-general-sopening-remarks-at-the-media-briefing-oncovid-19---11-march-2020 (accessed on 11/ Mar/2020).

4. Garcia-Alamino JM. Aspectos epidemiológicos, clínica y mecanismos de control de la pandemia por SARS-Cov-2: situación en España. Enferm Clin 2021; 31:S4-11.

5. Nussbaumer-Streit B, Mayr V, Dobrescu AI, Chapman A, Persad E, Klerings I, et al. Quarantine alone or in combination with other public health measures to control COVID-19: a rapid review. Cochrane Database Syst Rev 2020; (4):CD013574.

6. Conti AA. Historical and methodological highlights of quarantine measures: from ancient plague epidemics to current coronavirus disease (COVID-19) pandemic. Acta Biomed 2020; 91:226-9.

7. Mascha EJ, Schober P, Schefold JC, Stueber F, Luedi MM. Staffing with disease-based epidemiologic indices may reduce shortage of intensive care unit staff during the COVID-19 pandemic. Anesth Analg 2020; 131:24-30.

8. Qiu Y, Chen X, Shi W. Impacts of social and economic factors on the transmission of coronavirus disease 2019 (COVID-19) in China. J Popul Econ 2020; 9:1-46.

9. Aquino EML, Silveira IH, Pescarini JM, Aquino R, Souza-Filho JA; Grupo de Síntese da Rede CoVida. Social distancing measures to control the COVID-19 pandemic: potential impacts and challenges in Brazil. Ciênc Saúde Colet 2020; 25 Suppl 1:2423-46.

10. Szwarcwald CL, Souza Júnior PRB, Damacena GN, Malta DC, Barros MBA, Romero DE, et al. ConVid - Pesquisa de Comportamentos pela Internet durante a pandemia de COVID-19 no Brasil: concepção e metodologia de aplicação. Cad Saúde Pública 2021; 37:e00268320.

11. Victora CG, Huttly SR, Fuchs SC, Olinto MT. The role of conceptual frameworks in epidemiological analysis: a hierarchical approach. Int J Epidemiol 1997; 26:224-7.

12. Lima S, Carvalho ML, Vasconcelos AG. Proposta de modelo hierarquizado aplicado à investigação de fatores de risco de óbito infantil neonatal. Cad Saúde Pública 2008; 24:1910-6.
13. Meireles AL, Xavier CC, Andrade AC, Friche AA, Proietti FA, Caiaffa WT. Self-rated health in urban adults, perceptions of the physical and social environment, and reported comorbidities: The BH Health Study. Cad Saúde Pública 2015; 31 Suppl 1:S120-35.

14. Azevedo Barros MB, Lima MG, Medina LP, Szwarcwald CL, Malta DC. Social inequalities in health behaviors among Brazilian adults: National Health Survey, 2013. Int J Equity Health 2016; 15:148.

15. Theme Filha MM, Szwarcwald CL, Souza Junior PR. Measurements of reported morbidity and interrelationships with health dimensions. Rev Saúde Pública 2008; 42:73-81.

16. Werneck AO, Stubbs B, Fernandes RA, Szwarcwald CL, Silva DR. Leisure time physical activity reduces the association between TV-viewing and depressive symptoms: a large study among 59,401 Brazilian adults. J Affect Disord 2019; 252:310-4.

17. Malta DC, Bernal RTI, Vieira Neto E, Curci KA, Pasinato MTM, Lisbôa RM, et al. Trends in risk and protective factors for non-communicable diseases in the population with health insurance in Brazil from 2008 to 2015. Rev Bras Epidemiol 2018; 21 Suppl 1:e180020.

18. Martikainen P, Adda J, Ferrie JE, Smith GD, Marmot M. Effects of income and wealth on GHQ depression and poor self rated health in white collar women and men in the Whitehall II study. J Epidemiol Community Health 2003; 57:718-23.

19. Feng Q, Zhu H, Zhen Z, Gu D. Self-rated health, interviewer-rated health, and their predictive powers on mortality in old age. J Gerontol B Psychol Sci Soc Sci 2016; 71:53850.

20. Nielsen TH. The relationship between selfrated health and hospital records. Health Econ 2016; 25:497-512.

21. Froom P, Melamed S, Triber I, Ratson NZ, Hermoni D. Predicting self-reported health: the CORDIS study. Prev Med 2004; 39:419-23.

22. Mithen J, Aitken Z, Ziersch A, Kavanagh AM. Inequalities in social capital and health between people with and without disabilities. Soc Sci Med 2015; 126:26-35.

23. Chiu M, Amartey A, Wang X, Vigod S, Kurdyak P. Trends in objectively measured and perceived mental health and use of mental health services: a population-based study in Ontario, 2002-2014. CMAJ 2020; 192:E329-37.

24. Chandu VC, Pachava S, Vadapalli V, Marella Y. Development and initial validation of the COVID-19 Anxiety Scale. Indian J Public Health 2020; 64 Suppl:S201-4.

25. Wang C, Pan R, Wan X, Tan Y, Xu L, Ho CS, et al. Immediate psychological responses and associated factors during the initial stage of the 2019 coronavirus disease (COVID-19) epidemic among the general population in China. Int J Environ Res Public Health 2020; 17:1729. 
26. Hawkley LC, Cacioppo JT. Loneliness and pathways to disease. Brain Behav Immun 2003; 17 Suppl 1:S98-105.

27. Mukhtar S. Psychological health during the coronavirus disease 2019 pandemic outbreak. Int J Soc Psychiatry 2020; 66:512-6.

28. Satici B, Saricali M, Satici SA, Griffiths MD. Intolerance of uncertainty and mental wellbeing: serial mediation by rumination and fear of COVID-19. Int J Ment Health Addict 2020;15:1-12.

29. Huet F, Prieur C, Schurtz G, Gerbaud E, Manzo-Silberman S, Vanzetto G, et al. One train may hide another: acute cardiovascular diseases could be neglected because of the COVID-19 pandemic. Arch Cardiovasc Dis 2020; 113:303-7.

30. Rosenkranz RR, Duncan MJ, Rosenkranz SK, Kolt GS. Active lifestyles related to excellent self-rated health and quality of life: cross sectional findings from 194,545 participants in The 45 and Up Study. BMC Public Health 2013; 13:1071.

31. Lazarevich I, Irigoyen-Camacho ME, Velázquez-Alva MC. Obesity, eating behaviour and mental health among university students in Mexico City. Nutr Hosp 2013; 28:1892-9.

32. Andrade-Lima A, Werneck AO, Szwarcwald CL, Schuch FB, Stubbs B, Bastos AA, et al. The role of physical activity in the association between multimorbidity and depressive symptoms: data from 60,202 adults from the Brazilian National Health Survey. J Psychosom Res 2020; 134:110122.

33. Malta DC, Oliveira TP, Luz M, Stopa SR, Silva Júnior JB, Reis AA. Smoking trend indicators in Brazilian capitals, 2006-2013. Ciênc Saúde Colet 2015; 20:631-40.

34. Szwarcwald CL, Damacena GN, Souza Júnior PR, Almeida WS, Lima LT, Malta DC, et al. Determinants of self-rated health and the influence of healthy behaviors: results from the National Health Survey, 2013. Rev Bras Epidemiol 2015; 18 Suppl 2:33-44.
35. Reis RS, Kelly CM, Parra DC, Barros M, Gomes G, Malta D, et al. Developing a research agenda for promoting physical activity in Brazil through environmental and policy change. Rev Panam Salud Pública 2012; 32:93-100.

36. Werneck AO, Stubbs B, Szwarcwald CL, Silva DR. Independent relationships between different domains of physical activity and depressive symptoms among 60,202 Brazilian adults. Gen Hosp Psychiatry 2020; 64:26-32.

37. Kadariya S, Gautam R, Aro AR. Physical activity, mental health, and wellbeing among older adults in South and Southeast Asia: a scoping review. Biomed Res Int 2019; 2019:6752182.

38. Bontrup C, Taylor WR, Fliesser M, Visscher R, Green T, Wippert PM, et al. Low back pain and its relationship with sitting behaviour among sedentary office workers. Appl Ergon 2019; $81: 102894$.

39. Szwarcwald CL, Souza Júnior PR, Damacena GN, Barbosa Júnior A, Kendall C. Analysis of data collected by RDS among sex workers in 10 Brazilian cities, 2009: estimation of the prevalence of HIV, variance, and design effect. J Acquir Immune Defic Syndr 2011; 57 Suppl 3:S129-35.

40. Bezerra MAM, Hellwig N, Pinheiro GRC, Lopes CS. Prevalence of chronic musculoskeletal conditions and associated factors in Brazilian adults - National Health Survey. BMC Public Health 2018; 18:287.

41. Malta DC, Duncan BB, Schmidt MI, Machado IE, Silva AGD, Bernal RTI, et al. Prevalence of diabetes mellitus as determined by glycated hemoglobin in the Brazilian adult population, National Health Survey. Rev Bras Epidemiol 2019; 22 Suppl 2:e190006.supl.2. 


\section{Resumo}

O estudo transversal investigou fatores que afetam a autopercepção de saúde dos brasileiros durante pandemia da COVID-19, com base em dados de um inquérito comportamental eletrônico. Realizado entre 24 de abril e 24 de maio de 2020, o estudo recrutou participantes através de um procedimento de amostragem em cadeia. A variável de desfecho era a piora na autopercepção de saúde durante a pandemia. A análise estatística usou um modelo hierárquico de determinação. Foram utilizados modelos de regressão logística para testar as associações entre características sociodemográficas, doenças preexistentes, indicadores de estilo de vida $e$ intensidade de medidas de distanciamento social, $e$ aspectos biológicos e psicológicos durante a pandemia. Na amostra total de 45.161 participantes, $29,4 \%$ relataram piora do estado de saúde durante a pandemia. Após ajustar para fatores hierárquicos distais, os problemas de saúde mais associados à piora do estado de saúde foram: autopercepção de saúde ruim (OR ajustado $=4,35, p<0,001)$ : e procura de assistência devido a problemas de saúde mental $(O R$ ajustado $=3,95, p<0,001)$ e para COVID-19 (OR ajustado = 3,60, $p<0,001)$. As pessoas que relataram problemas de sono, piora da dor lombar, depressão e pelo menos um sintoma gripal durante a pandemia apresentavam duas vezes maior probabilidade de relatar piora do estado de saúde. Comportamentos sedentários e alimentares e adesão a medidas de distanciamento social mostraram correlação significativa com o desfecho. Há uma correlação entre fatores sociais, biológicos e psicológicos, mediada por estilos de vida e variáveis relacionadas ao confinamento. Juntos, esses fatores têm afetado negativamente a autopercepção de saúde dos brasileiros durante a pandemia da COVID-19.

COVID-19; Pandemias; Inquéritos

Epidemiológicos

\section{Resumen}

Se trata de un estudio transversal que investiga los factores que afectan la salud autoevaluada de los brasileños durante la pandemia de COVID-19, basada en datos de una encuesta por internet sobre comportamiento. Se llevó a cabo del 24 de abril al 24 de mayo de 2020, la encuesta reclutó participantes mediante un método de muestreo en cadena. Su resultado fue el empeoramiento de la salud autoevaluada durante la pandemia. El análisis estadístico estuvo basado en un modelo jerárquico de determinación. Los modelos de regresión logística se usaron para probar las asociaciones entre características sociodemográficas, condiciones de salud preexistentes, indicadores de estilo de vida e intensidad de las medidas de distanciamiento social, y problemas biológicos y psicológicos durante la pandemia. De una muestra total de 45.161 participantes, un 29,4\% informaron de un empeoramiento del estado de salud durante este periodo. Tras el ajuste por factores jerárquicos distales, los problemas de salud en su mayoría asociados con un empeoramiento del estado de salud fueron: mala salud autoevaluada (OR ajustada $=4,35$, $p<0,001)$, búsqueda de cuidados de salud por problemas mentales (OR ajustada $=3,95, p<0,001)$, $y$ en el caso del COVID-19 (OR ajustada = 3,60, $p<0,001)$. Las personas que sufrieron problemas de sueño, empeoramiento del dolor de espalda, depresión y al menos un síntoma de gripe durante la pandemia tuvieron dos veces más probabilidades de informar de un empeoramiento del estado de salud. Sedentarismo y comportamientos alimenticios, así como la adherencia a las medidas de distanciamiento social mostraron una significativa correlación con el resultado. Existe una relación entre los factores sociales, biológicos, y psicológicos, influenciados por los estilos de vida y variables relacionadas con el confinamiento. En conjunto, estos factores han afectado negativamente la salud autoinformada durante la pandemia de COVID-19 en Brasil.

COVID-19; Pandemias; Encuestas

Epidemiológicas
Submitted on $25 /$ Jun/2020

Final version resubmitted on $21 / \mathrm{Jul} / 2020$

Approved on 28/Jul/2020 